\title{
Mesenchymal Stem Cells in Hematopoietic Stem Cell Transplantation
}

\author{
Minoo Battiwalla, MD, MS ${ }^{a}$ and Peiman Hematti, MD ${ }^{b, c}$ \\ a Department of Medicine, Roswell Park Cancer Institute \\ ${ }^{b}$ Department of Medicine, University of Wisconsin-Madison, School of Medicine and Public Health, \\ Madison, Wisconsin \\ c University of Wisconsin Paul P. Carbone Comprehensive Cancer Center, Madison, Wisconsin
}

\begin{abstract}
Mesenchymal stromal/stem cells (MSCs) of bone marrow (BM) origin not only provide the supportive microenvironmental niche for hematopoietic stem cells (HSCs) but are also capable of differentiating into various cell types of mesenchymal origin, such as bone, fat, and cartilage. In vitro and in vivo data suggest that MSCs have low inherent immunogenicity, modulate/suppress immunological responses through interactions with immune cells, and home to damaged tissues to participate in regeneration processes through their diverse biological properties. MSCs derived from $\mathrm{BM}$ are being evaluated for a wide range of clinical applications including disorders as diverse as myocardial infarction or newly diagnosed diabetes mellitus type-1. However, their use in HSC transplantation, either for enhancement of hematopoietic engraftment or for treatment/prevention of graft versus host disease, is far ahead of other indications. Ease of isolation and ex vivo expansion of MSCs, combined with their intriguing immunomodulatory properties, and their impressive record of safety in a wide variety of clinical trials make these cells promising candidates for further investigation.
\end{abstract}

\section{Index words}

mesenchymal stem cells; mesenchymal stromal cells; hematopoietic stem cells; graft versus host disease; engraftment; BMT

\section{Introduction}

Friedenstein et al. were the first to characterize bone marrow (BM) stromal cells, an adherent, fibroblast-like population in the adult BM capable of regenerating rudiments of bone in vivo [1]. These cells which comprise a very small population $(<0.1 \%)$ of adult BM cells, provide the supportive niche for hematopoietic stem cells (HSCs); however, recent studies favor osteoblasts, a progeny of MSCs, as the main cell involved in HSC niche [2]. Caplan was the first to use the term mesenchymal stem cells (MSCs) to reflect their capability to differentiate into other cells of mesenchymal lineage such as fat and cartilage [3]. MSCs are most commonly isolated/culture-expanded by plating BM mononuclear cells in culture plates, followed by serial passage of the adherent cells. Interestingly, three decades after their original description, there is still much controversy about their exact anatomical location inside BM, true

Corresponding Author: Peiman Hematti, MD, Hematology Office H4/534 CSC-5156, 600 Highland Avenue, Madison, WI 53792-5156, pxh@ medicine.wisc.edu, Tel: (608) 265-0106, Fax: (608) 262-1982. 
physiological role, and their multilineage differentiation[4]. To better reflect the true identity of these cells recently the term multipotent mesenchymal stromal cells (with the same acronym as MSCs) has been recently proposed as the preferred terminology, accompanied with a specific set of criteria to avoid confusion in the field [5].

MSCs have generated a lot of excitement in the field of regenerative medicine over the last decade due to their potential to differentiate into a variety of cell types, their migration to sites of injury or inflammation after intravenous infusion, their ability to stimulate proliferation and differentiation of resident progenitor cells, and promote recovery of damaged tissues through secretion of a variety of cytokines and chemokines [6-13]. Intriguingly, an emerging body of evidence shows that MSCs possess immunomodulatory properties beneficial in many disease processes [14-16]. MSCs do not induce lymphocyte proliferation in vitro and are not targets for cytotoxic T cells or NK cells [17-20]. Consequently, they could be tolerated when transplanted over major histocompatibility complex barriers in humans [21]. Based on these immunomodulatory and immunoprivileged characteristics, many human studies have used ex vivo expanded BM-derived-MSCs from HLA-mismatched "third party" donors. Thus far, culture-expanded MSCs derived from BM, and to a more limited extent, MSCs derived from other tissues such as fat, have been used in several small phase I-II trials for a variety of non hematological indications including treatment of patients with metachromatic leukodystrophy and Hurler's disease [22], osteogenesis imperfecta [23], myocardial infarction [24,25], amyotrophic lateral sclerosis [26-28], stroke [29], Crohn's disease [30], diabetes mellitus [31] refractory wounds [32], among others [33]. However, in this review we will focus on the use of MSCs in HSC transplantation, based on their myriad biological properties relevant to this field (Figure-10). Cytotherapy has recently published several excellent reviews on the use of MSCs for other indications [34-36].

MSCs are part of the bone marrow stromal microenvironment and their fate during allogeneic stem cell transplantation has been studied. Interestingly, recipient MSCs mostly survive myeloablative conditioning regimens and the majority of studies done so far have shown post transplant MSCs are predominantly recipient-derived [37-39]. Thus, although donor MSCs comprise a fraction of marrow grafts they do not replace recipient MSCs despite the achievement of complete donor lymphohematopoietic engraftment, likely reflecting their relatively small numbers in vivo, their poor engraftment, or other unknown factors. In animal transplant models, donor MSCs first migrate to the lung and then other internal organs, such as the spleen and intestine. Recent studies suggest that a state of robust engraftment is not a prerequisite for MSCs to mediate their effects [40]. Indeed, we argue that this could be a potential advantageous property of these cells, as they mediate their clinically favorable effects and then disappear, thus eliminating the risk of inducing unwanted effects later. This could also explain why usually repeated infusions of MSCs are needed to achieve a clinical effect.

There is enormous heterogeneity in the production methodologies for MSCs as currently there is no standard culture method [41-43]. Bone marrow derived MSCs are usually cultured from small volume (25-50 ml) BM aspirates. MSCs are present in the mononuclear cell (MNC) fraction of the $\mathrm{BM}$; the MNC fraction is usually separated using density gradient centrifugation followed by culturing cells in media supplemented with fetal bovine serum. Usually twentyfour hours to several days later nonadherent cells are removed and the adherent cells are fed with culture media changes every 3-4 days. When the cells reach near confluence they are trypsinized and passaged into new culture plates. At low passage, such cultures contain other cells; however, after a few passages there will be a homogenous population of cells resembling fibroblasts. Nevertheless, despite their seemingly similar morphologies the ultimate identity of such cells could depend on numerous factors such as: starting source of the cells, age of the donor, density of the cells plated, and type of media and serum used. For example, the use of FBS generates concern about the potential risk of transmitting animal diseases of yet unknown 
origin and also for potential reaction to antigens of animal origin. Alternatives to FBS that have been investigated include serum free media, autologous serum, fresh frozen plasma, and human platelet lysates [44-46]. These variations in the culture methodologies could easily affect the immunomodulatory properties of MSCs and thus confound the interpretation of results of different studies; furthermore, as with many other cellular therapies there is no clinically applicable potency assay for MSCs. Another important factor to consider is the passage of the cells used for therapeutic purposes, as early passages carry hematopoietic impurities, which may affect the clinical results observed, and later passages carry the increasing risk of acquiring potential mutagenic characteristics.

\section{MSCs to enhance engraftment after HSCT}

Primary graft failure is a devastating early complication of allogeneic HSCT and is usually caused by immunologic resistance versus incoming hematopoietic progenitors or by an inadequate number of progenitors. The incidence of graft failure is $<5 \%$ in fully ablative HLAmatched transplants but can be a significant issue in subjects who receive less intense conditioning, HLA-mismatched grafts (including cord blood transplants) or in recipients who are HLA-alloimmunized. Due to the presumed contribution of MSCs to hematopoiesis and also based on animal studies in which co-transplantation of MSCs with HSCs improved engraftment of the latter $[47,48]$, MSCs have been investigated for their ability to improve engraftment in allogeneic stem cell transplants. Clinical studies of MSCs for enhancement of engraftment are summarized in Table-1.

Lazarus et al. were first to report a phase I trial to determine feasibility of collection, ex vivo culture-expansion, and intravenous infusion of human BM-derived MSCs (referred to as "mesenchymal progenitor cells" in this original report) [49]. Investigators collected and culture-expanded MSCs from $10 \mathrm{ml} \mathrm{BM}$ aspirates from 23 patients with hematologic malignancies in complete remission, 12 of them have previously had an autologous or syngeneic bone marrow transplant. Autologous MSCs were reinfused intravenously after 4-7 weeks of ex vivo expansion into 15 patients. No adverse reactions were observed with infusion of MSCs. Thus, this study showed the feasibility of culturing MSCs from small volume BM samples using clinically acceptable methodologies, and their safety in infusion.

The same group subsequently conducted a phase I-II clinical trial with a therapeutic intent to determine feasibility, safety, and hematopoietic effects of culture-expanded autologous MSCs infused into 28 patients breast cancer patients after high-dose chemotherapy and autologous HSC transplantation [50] with the hypothesis that infusion of autologous MSCs after myeloablative conditioning would accelerate hematopoietic recovery. MSCs again were culture-expanded from a small bone marrow aspirate, and were used after 2-6 passages at a dose of 1 to 2.2 millions MSC/Kg over 15 minutes. Again, autologous MSCs were infused without any toxicity and hematopoietic recovery was rapid; neutrophil engraftment $(\geq 500$ / $\mu \mathrm{L}$ ) was achieved in a median of 8 days and platelet count $\geq 20,000 / \mu \mathrm{L}$ (untransfused) in a median of 8.5 days. Despite the rapid hematopoietic recovery in this series of the patients firm conclusions regarding the engraftment promoting effect of MSCs could not be made due to the nonrandomized nature of the study [50]. Nevertheless, these studies provided further evidence that culture expansion of MSCs under good manufacturing practice conditions was feasible and these cells were safe to infuse.

Led by the Lazarus group in a multicenter clinical trial, culture-expanded allogeneic MSCs derived from BM of HLA-identical sibling donors were infused 4 hours before infusion of HSCs in 46 patients undergoing myeloablative HSC transplantation for various hematological malignancies using BM or peripheral blood HSCs [51]. There were no infusion-related toxicities, ectopic tissue formation, or increase in the incidence or severity of GVHD. However, 
in comparison with historical controls, no acceleration of hematopoietic engraftment was observed as the median times to engraftment of neutrophils $\geq 500 / \mu \mathrm{L}$ and platelets $\geq 20,000$ / $\mu \mathrm{L}$ (untransfused) were 14.0 days and 20.5 days, respectively. Furthermore, rates of acute and chronic GVHD in this study were similar to other comparable studies. Importantly, the authors suggested that culture-expanded MSCs from unrelated healthy HLA unmatched third-party donors could be potentially used as a universal donor product.

The safety of allogeneic or autologous ex vivo expanded BM-derived MSCs co-transplanted with HSCs in patients with hematologic and nonhematologic malignancies have been verified in other studies too. Le Blanc used MSC transplantation in three patients to prevent repeat graft rejection/failure after $\mathrm{HSC}$ re-transplantation, and in four patients to enhance hematopoietic engraftment after allogeneic HSC transplantation [52]. HSC donors were three HLA-matched siblings, three unrelated donors and one cord blood unit. MSC donors were HLA-matched siblings in three cases and haploidentical donors in the other four cases. Neutrophil engraftment $\geq 500 / \mu \mathrm{L}$ was achieved at a median of 12 days, and platelets $\geq 30,000 / \mu \mathrm{L}$ was achieved at a median of 12 days. Thus, co-transplantation of MSC resulted in fast engraftment and 100\% donor chimerism, even in three patients who were re-transplanted for previous graft failure/ rejections. Ball et al co-transplanted donor MSCs in 14 children undergoing HSC transplantation with G-CSF mobilized CD34+ cells selected from haploidentical donors. Compared to a graft failure rate of $15 \%$ in 47 historic controls, all these patients had sustained hematopoietic engraftment without any adverse reactions, suggesting that MSCs could potentially reduce the risk of graft failure in haploidentical HSC transplant recipients [53]. The authors hypothesized that MSCs reduced the rate of graft failure in these patients possibly through their immunosuppressive effect on alloreactive recipient $\mathrm{T}$ lymphocytes escaping the preparative regimen. In a single-institution phase I-II trial MacMillan et al. tested the potential of MSCs from haploidentical parental donors to accelerate hematopoietic recovery at the time of single unit umbilical cord blood transplantation. Fifteen patients were enrolled into this study but seven did not receive MSC infusions for a variety of reasons including insufficient number of MSCs available at the time of transplant in three cases. Eight patients received MSCs on the day of UCB transplant and three patients received a second dose infused on day 21. For the 5 patients who did not receive second dose of MSCs apparently insufficient growth of MSCs was the factor. All eight evaluable patients achieved neutrophil engraftment $(>500 / \mu \mathrm{L})$ at a median of 19 days and $75 \%$ probability of platelet engraftment (first day of a seven consecutive days of platelet counts $>50,000 / \mu \mathrm{L}$ ) at a median of 53 days. In this encouraging report with a median follow-up of 6.8 years, five patients remained alive and disease free at the time of report [54]. Fang et al co-transplanted adipose-tissue derived MSCs from haploidentical donors along with PB HSCs from HLA-matched siblings into two patients with sever aplastic anemia who had previously rejected HSCs from the same donors. At the time of report these two patients were transfusion-independent and in good condition more than two years after their co-transplantation [55].

\section{MSCs in graft versus host disease}

One of the most intriguing properties of ex vivo expanded MSCs is their ability to modulate the immune response in vitro and in vivo through interaction with a broad range of immune cells including T-lymphocytes, B-lymphocytes, natural killer and dendritic cells [56-59]. Acute GVHD is a T-cell mediated process, occurring in the first 100 days following allogeneic transplant or a donor lymphocyte infusion; and steroid-refractory GVHD has an extremely poor prognosis $[60,61]$. Years ago it was suggested that MSCs could be potentially useful for amelioration of GVHD after allogeneic HSC transplantation [62,63]. Studies investigating MSCs for the treatment or prevention of GVHD are summarized in Table-2. 
Le Blanc et al. were the first to report the potential of MSC infusion for the treatment of GVHD in a 9-year-old boy who received a matched unrelated donor HSC transplant for leukemia [64]. The patient developed severe acute GVHD of the gut and liver unresponsive to all types of immunosuppression including high dose methylprednisolone, infliximab and daclizumab. Haploidentical MSCs were generated from the patient's mother, not the original donor, and cells were harvested after three weeks of culture. After the infusion of one dose of MSCs, the GVHD subsided. Infusion of a second dose of MSCs from the same batch of original MSCs was also effective in treating GVHD when it recurred later. Importantly, no alloreactivity was detected when patient's lymphocytes were cultured with donors MSCs before or after MSC transplantation. This landmark report was followed by a larger study from the same group in which MSCs were given to eight patients with steroid-refractory grades III-IV GVHD and one with extensive chronic GVHD [65]. Two patients received MSCs from HLA-identical siblings, six from haplo-identical family donors, and four from unrelated mismatched donors. There were no acute toxicities after MSC infusions. Acute GVHD completely resolved in six of eight patients, but two died soon after MSC treatment without evidence of response. At the time of report five patients were alive between 2 months and 3 years after transplantation. This survival rate was significantly superior compared to a control group of 16 patients with treatmentrefractory acute gut GVHD who did not receive MSCs. Most recently the same group reported the administration of MSCs, derived from marrow and expanded according to the European Group for Blood and Marrow Transplantation ex-vivo expansion procedure, to 55 patients with steroid refractory GVHD in a multicenter, phase II trial. The median dose of MSCs was $1.4 \times 10^{6}$ (range $\left.0.4-9 \times 10^{6}\right) / \mathrm{kg}$ derived from multiple donor sources; some even received MSCs from multiple donors. Complete responses occurred in 30 patients. Two years later, 53\% of the complete responders were still alive vs. $16 \%$ of non-responders [66]. This largest prospective clinical trial reported to date showed that, interestingly, GVHD responses were independent of the source of MSCs; i.e. use of HLA-identical sibling, haplo-identical, and third-party HLA-mismatched donors showed similar results. This will have a major impact in future trials as generation of donor specific MSCs is time consuming, costly, and in many occasions impractical due to the urgent nature of its use.

Von Bonin reported 13 patients with steroid-refractory acute GVHD who received BM-derived MSC that were expanded in platelet lysate-containing medium from unrelated HLA disparate donors [67]. In this group of patients the median number of MSC infusions was 2 (range 1-5) and MSCs were initiated at a median of 16 days after the onset of GVHD. Only two patients $(15 \%)$ did not need further escalation of their immunosuppressive regimen after the first dose of MSCs, whereas, eleven patients received additional salvage immunosuppressive therapy along with more MSC infusions, with five of the latter group showed a response after 28 days. Four patients (31\%) were alive after a median follow-up of 257 days. Lower response rate in this co-cohort of patient compared to other reports could have, potentially, been due to use platelet lysate-containing medium in the culture methodology, number of MSC infusions, cell dose, or other factors such as the interval between development of GVHD and the first dose of MSCs. Results reported by Muller at al. using MSCs in pediatric patients who had received HSC transplantation was also less impressive [68]. MSCs were isolated from the respective HSC donors in five cases and from a third party parental donor in the other two cases.

Interestingly, one patient who had trilineage failure due to severe hemophagocytosis showed decrease in her hemophagocytosis after receiving MSCs and then had complete improvement after a subsequent second HSC transplant.

Ning et al. in an open-label randomized trial used HLA-matched sibling HSC transplantation with (10 patients) or without (15 patients) MSCs for treatment of hematologic malignancies. The median time to neutrophil engraftment or platelet engraftment was not different between these groups, however, grades II-IV acute GVHD was observed in only one (11.1\%) of MSC group versus eight $(53.3 \%)$ of non-MSC evaluable patients. Significantly, the number of 
patients who relapsed were six (60.0\%) in MSC group and three (20.0\%) in non-MSC group with a 3 -year disease-free survival of 30.0 and $66.7 \%$, respectively. The authors concluded that co-transplantation of MSCs and HSCs may prevent GVHD, but may be associated with a higher rate of relapse [69]. In this group only two patients could receive the planned dose of MSCs at $1-2 \times 10^{6} / \mathrm{kg}$ and as a result the MSC dose in this study was $0.03-1.5 \times 10^{6} / \mathrm{kg}$, which is lower than most others studies. Also, in contrast to most other studies which use passage 2-3 MSCs, in this study cells from passage-1 were used for infusion.

Patient enrollment has just been completed in a Phase III trial investigating the potential of MSCs for the treatment of steroid-refractory acute GVHD using Prochymal ${ }^{\circledR}$, a proprietary formulation of MSCs derived from the marrow of healthy third-party donors. This definitive double-blinded, placebo controlled trial was designed to assess safety and efficacy of Prochymal over a six-month period. A total of 244 patients, including 27 pediatric patients, were enrolled at $72 \mathrm{HSC}$ transplant centers across the United States, Canada, Europe, and Australia. More recently, patient enrollment $(\mathrm{n}=190)$ has also completed in a Phase III doubleblind, placebo-controlled trial evaluating Prochymal ${ }^{\circledR}$ as a first-line treatment for acute GVHD. In both studies patients were randomized to either Prochymal® or placebo in a 2:1 ratio. Prochymal ${ }^{\circledR}$ has already been granted "Fast Track" status by FDA for these indications. Results of these studies are highly anticipated due to the large number of patients involved, its double blind randomized nature, and the consistency in cell dose and MSC preparation. However, there are variables that may confound results such as differences in treatment regimens used in different centers.

\section{MSCs for tissue repair after HSC transplantation}

In addition to promoting hematopoietic engraftment and prevention and/or treatment of GVHD MSCs have been used to treat other complications after HSC transplantation based on their tissue regenerative properties (Table-3). Ringden et al treated ten patients with MSCs that had a variety of tissue/organ toxicities following allogeneic HSC transplantation, including seven with hemorrhagic cystitis, two with pneumomediastinum and one with perforated colon and peritonitis [70]. MSC donors were unrelated HLA-mismatched ( $\mathrm{n}=11)$, HLA-haploidentical $(n=3)$ and, HLA-matched sibling donors $(n=2)$. In five patients, the severe hemorrhagic cystitis resolved after MSC infusion. MSC infusion resulted in a reduction in transfusion requirements in two patients but one died of multiorgan failure and one from progressive GVHD. In two patients, pneumomediastinum resolved after MSC infusions. A patient with steroid-refractory GVHD of the gut developed perforated diverticulitis and peritonitis and refused surgery; she recovered after MSC infusion. However, she later developed recurrent peritonitis and although she responded a second time, later died of disseminated fungal infection. [48] It is expected that in the future we will see more use of MSCs in similar conditions [71].

\section{MSCs derived from non-BM origin}

Although MSCs were originally isolated from BM, cells with similar biological characteristics and differentiation potential have been isolated from a wide variety of other adult tissues including adipose tissue (AT) [72], neonatal tissues such as placenta [73] and umbilical cord blood [74], and fetal tissues such as lung, liver, and blood [75]. Adipose tissue has been proposed as another easily accessible source of MSCs suitable for clinical applications. Preclinical data suggest that AT-derived MSCs possess immunological characteristics similar to BM-derived MSCs [76-78], so, not surprisingly, AT-derived MSCs have been also used in a few small clinical trials. Fang et al describe two pediatric patients who developed severe refractory acute GVHD following HSC transplantation and then received adipose-tissue derived MSCs from HLA-mismatched unrelated donors. [79] In these two patients MSC infusion successfully treated grade- 4 gut GVHD and grade 3 liver GVHD. The same group 
also reported a 43-year-old woman with chronic hepatic GVHD who failed previous immunosuppressive therapy and was treated with adipose tissue-derived MSCs. The authors reported complete resolution of liver GVHD after infusion of MSCs from a mismatched donor [80]. Finally, the same authors reported treatment of six patients with steroid-refractory grades III-IV acute GVHD with adipose-tissue derived MSC, two from haplo-identical family donors and four from unrelated mismatched donors. According to this report acute GVHD disappeared completely in five of six patients, four of whom were alive, in good condition and in remission after a median follow-up of 40 months [81].

\section{MSCs and cord blood transplantation}

Infusion of third-party donor mobilized HSCs, depleted of T-cells, have been used combined with UCB transplantation as a "bridge engraftment" strategy till the engraftment of the latter [82]. Gonzalo-Daganzo et al investigated the potential of co-infusion of MSCs derived from third party HSC donors on CB engraftment and effects on prevention or treatment of acute GVHD in this type of transplantation [83]. MSCs were infused at the time of the transplant or in the case of refractory acute GVHD. Nine patients received MSCs immediately after CB and third party donor HSCs but no significant differences in CB engraftment or incidence of acute GVHD was observed compared to a control group of 46 patients who did not receive MSCs. Although not statistically significant, no patients in the MSC group developed grade III-IV GVHD. However, in MSC treated subjects, four patients developed grade II acute GVHD and two of them were steroid refractory. These two patients achieved complete remission after therapeutic infusions of MSCs.

Brooke $\mathrm{G}$ et al. reported the first case of clinical use of MSC isolated and expanded from placenta into a patient combined with UCB transplantation [84]. The patient, a 20 year old male with acute myeloid leukemia in second remission, received placenta derived MSCs, $1 \times 10^{6} / \mathrm{kg}$, after myeloablative conditioning and prior to receiving two cord blood units. He developed skin GVHD on day 14 which was successfully treated with steroids but died at day 68 due to interstitial pneumonia. Due to ease of isolation and culture expansion of MSCs from a variety of sources, and lack of need for HLA-matching it is expected that more studies will be conducted using MSCs from such diverse tissue sources.

\section{Conclusions}

The early clinical trials pioneered by visionary HSC transplant physicians have provided useful initial information and generated much excitement encouraging other disciplines of medicine to enter the field of MSC therapy, nevertheless, their use in HSC transplantation is far ahead of others. We can now conclude with a certain level of assurance that there have been no infusional toxicities with MSCs and the production of ectopic tissue has not been observed. However, due to the nature of these mostly small nonrandomized clinical trials, conclusive clinical benefit is hard to discern. Important questions remain to be addressed: How can the production of MSCs be standardized? What assays should be used to define potency? Is it possible that different passages of cells might have different immunomodulatory properties? Is it possible that use of serum free media might change the immunological properties of MSCs? Is it preferable to use autologous MSCs, if clinically practical, over allogeneic over third-party? What are the optimal dose and frequency of administration for MSCs for different indications? What is the optimal tissue of origin for MSCs for any given indication, BM or AT? What are the best additional immunosuppressive or preparative regimens to be combined with MSCs for different clinical indications? What safety assays should be used to verify genetic or phenotypic stability of transplanted cells? What is the ultimate fate of MSCs after transplantation? 
The most compelling results have come from phase II studies in steroid-refractory acute GVHD. MSCs are closest to regulatory approval for use in acute GVHD pending the results of the now fully-accrued phase III trials in the first-line and steroid-refractory settings. However, evidence for boosting engraftment is inconclusive. This indication will require large randomized trials in populations vulnerable to engraftment failure (such as cord blood transplants). However, one potential application for MSCs will be their use as in vitro bioreactors for expansion of hematopoietic stem cells, recapitulating their in vivo functionality; such studies have been already initiated [85,86]. Although the overwhelming majority of MSC studies have pointed to the safety and potential efficacy of these cells, these studies have also identified issues of concern. Most concerning is the theoretical increased risk of relapse, now documented by Ning, et al in a single controlled trial, and tumor promoting effects demonstrated in several animal models [87,88]. Durability of the infused MSCs is still a matter of great debate [40]. Although there have been documented instances of epithelial chimerism by high-resolution PCR-based assays in human studies, the extent of MSC engraftment is usually minimal. However, it is quite possible that MSCs exert their beneficial effects through unknown mechanisms prior to their demise; thus, lack of durability could be potentially advantageous as it may preclude chance of tumorigenicity in the future. Logistical considerations are immense: ignoring regulatory requirements, it takes at least four weeks to expand autologous MSCs and many trial subjects have been unable to receive their target dose of MSCs. In this respect, the finding that third party MSCs are equally effective in treating GVHD and safe to administer, suggest that this could be the solution of choice in urgent indications. Ease of production of MSCs according to GMP guidelines, their apparent lack of immunogenicity, and their impressive safety records, so far, warrants continued investigation in their already exploding applications. However, carefully designed clinical trials will be necessary to define the optimum dose, schedule, source, route of administration, and indications for MSCs.

\section{References}

1. Friedenstein AJ, Petrakova KV, Kurolesova AI, Frolova GP. Heterotopic of bone marrow. Analysis of precursor cells for osteogenic and hematopoietic tissues. Transplantation 1968 Mar;6(2):230-47. [PubMed: 5654088]

2. Wu JY, Scadden DT, Kronenberg HM. Role of the osteoblast lineage in the bone marrow hematopoietic niches. J Bone Miner Res 2009 May;24(5):759-64. [PubMed: 19257832]

3. Caplan AI. Mesenchymal stem cells. J Orthop Res 1991 Sep;9(5):641-50. [PubMed: 1870029]

4. Javazon EH, Beggs KJ, Flake AW. Mesenchymal stem cells: paradoxes of passaging. Experimental hematology 2004 May;32(5):414-25. [PubMed: 15145209]

5. Dominici M, Le BK, Mueller I, Slaper-Cortenbach I, Marini F, Krause D, et al. Minimal criteria for defining multipotent mesenchymal stromal cells. The International Society for Cellular Therapy position statement. Cytotherapy 2006;8(4):315-7. [PubMed: 16923606]

6. Gao J, Dennis JE, Muzic RF, Lundberg M, Caplan AI. The dynamic in vivo distribution of bone marrow-derived mesenchymal stem cells after infusion. Cells, tissues, organs 2001;169(1):12-20. [PubMed: 11340257]

7. Devine SM, Cobbs C, Jennings M, Bartholomew A, Hoffman R. Mesenchymal stem cells distribute to a wide range of tissues following systemic infusion into nonhuman primates. Blood 2003 Apr 15;101 (8):2999-3001. [PubMed: 12480709]

8. Mouiseddine M, Francois S, Semont A, Sache A, Allenet B, Mathieu N, et al. Human mesenchymal stem cells home specifically to radiation-injured tissues in a non-obese diabetes/severe combined immunodeficiency mouse model. The British journal of radiology 2007 Sep;80(Spec No 1):S49-55. [PubMed: 17704326]

9. Caplan AI. Adult mesenchymal stem cells for tissue engineering versus regenerative medicine. J Cell Physiol 2007 Nov;213(2):341-7. [PubMed: 17620285] 
10. Pittenger MF, Mackay AM, Beck SC, Jaiswal RK, Douglas R, Mosca JD, et al. Multilineage potential of adult human mesenchymal stem cells. Science 1999;284(5411):143-7. [PubMed: 10102814]

11. Keating A. Mesenchymal stromal cells. Current opinion in hematology 2006 Nov;13(6):419-25. [PubMed: 17053453]

12. Prockop DJ. "Stemness" does not explain the repair of many tissues by mesenchymal stem/multipotent stromal cells (MSCs). Clinical pharmacology and therapeutics 2007 Sep;82(3):241-3. [PubMed: 17700588]

13. Le Blanc K, Pittenger M. Mesenchymal stem cells: progress toward promise. Cytotherapy 2005;7(1): 36-45. [PubMed: 16040382]

14. Uccelli A, Pistoia V, Moretta L. Mesenchymal stem cells: a new strategy for immunosuppression? Trends in immunology 2007 May;28(5):219-26. [PubMed: 17400510]

15. Le Blanc K, Ringden O. Immunobiology of human mesenchymal stem cells and future use in hematopoietic stem cell transplantation. Biol Blood Marrow Transplant 2005 May;11(5):321-34. [PubMed: 15846285]

16. Prockop DJ, Olson SD. Clinical trials with adult stem/progenitor cells for tissue repair: let's not overlook some essential precautions. Blood 2007 Apr 15;109(8):3147-51. [PubMed: 17170129]

17. Tse WT, Pendleton JD, Beyer WM, Egalka MC, Guinan EC. Suppression of allogeneic T-cell proliferation by human marrow stromal cells: implications in transplantation. Transplantation 2003 Feb 15;75(3):389-97. [PubMed: 12589164]

18. Le Blanc K, Tammik C, Rosendahl K, Zetterberg E, Ringden O. HLA expression and immunologic properties of differentiated and undifferentiated mesenchymal stem cells. Experimental hematology 2003 Oct;31(10):890-6. [PubMed: 14550804]

19. Klyushnenkova E, Mosca JD, Zernetkina V, Majumdar MK, Beggs KJ, Simonetti DW, et al. T cell responses to allogeneic human mesenchymal stem cells: immunogenicity, tolerance, and suppression. Journal of biomedical science 2005;12(1):47-57. [PubMed: 15864738]

20. Rasmusson I, Ringden O, Sundberg B, Le Blanc K. Mesenchymal stem cells inhibit the formation of cytotoxic T lymphocytes, but not activated cytotoxic T lymphocytes or natural killer cells. Transplantation 2003 Oct 27;76(8):1208-13. [PubMed: 14578755]

21. Le Blanc K, Gotherstrom C, Ringden O, Hassan M, McMahon R, Horwitz E, et al. Fetal mesenchymal stem-cell engraftment in bone after in utero transplantation in a patient with severe osteogenesis imperfecta. Transplantation 2005 Jun 15;79(11):1607-14. [PubMed: 15940052]

22. Koc ON, Day J, Nieder M, Gerson SL, Lazarus HM, Krivit W. Allogeneic mesenchymal stem cell infusion for treatment of metachromatic leukodystrophy (MLD) and Hurler syndrome (MPS-IH). Bone marrow transplantation 2002 Aug;30(4):215-22. [PubMed: 12203137]

23. Horwitz EM, Prockop DJ, Fitzpatrick LA, Koo WW, Gordon PL, Neel M, et al. Transplantability and therapeutic effects of bone marrow-derived mesenchymal cells in children with osteogenesis imperfecta. Nature medicine 1999 Mar;5(3):309-13.

24. Chen SL, Fang WW, Ye F, Liu YH, Qian J, Shan SJ, et al. Effect on left ventricular function of intracoronary transplantation of autologous bone marrow mesenchymal stem cell in patients with acute myocardial infarction. The American journal of cardiology 2004 Jul 1;94(1):92-5. [PubMed: 15219514]

25. Schuleri KH, Boyle AJ, Hare JM. Mesenchymal stem cells for cardiac regenerative therapy. Handbook of experimental pharmacology 2007;(180):195-218. [PubMed: 17554510]

26. Mazzini L, Mareschi K, Ferrero I, Vassallo E, Oliveri G, Boccaletti R, et al. Autologous mesenchymal stem cells: clinical applications in amyotrophic lateral sclerosis. Neurological research $2006 \mathrm{Jul} ; 28$ (5):523-6. [PubMed: 16808883]

27. Deda H, Inci MC, Kurekci AE, Sav A, Kayihan K, Ozgun E, et al. Treatment of amyotrophic lateral sclerosis patients by autologous bone marrow-derived hematopoietic stem cell transplantation: a 1year follow-up. Cytotherapy 2009;11(1):18-25. [PubMed: 19012065]

28. Martinez HR, Gonzalez-Garza MT, Moreno-Cuevas JE, Caro E, Gutierrez-Jimenez E, Segura JJ. Stem-cell transplantation into the frontal motor cortex in amyotrophic lateral sclerosis patients. Cytotherapy 2009;11(1):26-34. [PubMed: 19191058]

29. Bang OY, Lee JS, Lee PH, Lee G. Autologous mesenchymal stem cell transplantation in stroke patients. Annals of neurology 2005 Jun;57(6):874-82. [PubMed: 15929052] 
30. Taupin P. OTI-010 Osiris Therapeutics/JCR Pharmaceuticals. Curr Opin Investig Drugs 2006 May; 7(5):473-81.

31. Abdi R, Fiorina P, Adra CN, Atkinson M, Sayegh MH. Immunomodulation by mesenchymal stem cells: a potential therapeutic strategy for type 1 diabetes. Diabetes 2008 Jul;57(7):1759-67. [PubMed: 18586907]

32. Yoshikawa T, Mitsuno H, Nonaka I, Sen Y, Kawanishi K, Inada Y, et al. Wound therapy by marrow mesenchymal cell transplantation. Plastic and reconstructive surgery 2008 Mar;121(3):860-77. [PubMed: 18317135]

33. Giordano A, Galderisi U, Marino IR. From the laboratory bench to the patient's bedside: An update on clinical trials with mesenchymal stem cells. J Cell Physiol 2007 Jan 16;211(1):27-35. [PubMed: 17226788]

34. Jethva R, Otsuru S, Dominici M, Horwitz EM. Cell therapy for disorders of bone. Cytotherapy 2009;11(1):3-17. [PubMed: 19191055]

35. Herdrich BJ, Lind RC, Liechty KW. Multipotent adult progenitor cells: their role in wound healing and the treatment of dermal wounds. Cytotherapy 2008;10(6):543-50. [PubMed: 18836914]

36. Cannon RO 3rd, Dunbar CE. BM-derived cell therapies for cardiovascular disease. Cytotherapy 2007;9(4):305-15. [PubMed: 17573606]

37. Koc ON, Peters C, Aubourg P, Raghavan S, Dyhouse S, DeGasperi R, et al. Bone marrow-derived mesenchymal stem cells remain host-derived despite successful hematopoietic engraftment after allogeneic transplantation in patients with lysosomal and peroxisomal storage diseases. Experimental hematology 1999 Nov;27(11):1675-81. [PubMed: 10560915]

38. Rieger K, Marinets O, Fietz T, Korper S, Sommer D, Mucke C, et al. Mesenchymal stem cells remain of host origin even a long time after allogeneic peripheral blood stem cell or bone marrow transplantation. Experimental hematology 2005 May;33(5):605-11. [PubMed: 15850839]

39. Awaya N, Rupert K, Bryant E, Torok-Storb B. Failure of adult marrow-derived stem cells to generate marrow stroma after successful hematopoietic stem cell transplantation. Experimental hematology 2002 Aug;30(8):937-42. [PubMed: 12160845]

40. Uccelli A, Moretta L, Pistoia V. Mesenchymal stem cells in health and disease. Nature reviews 2008 Sep;8(9):726-36.

41. Samuelsson H, Ringden O, Lonnies H, Le Blanc K. Optimizing in vitro conditions for immunomodulation and expansion of mesenchymal stromal cells. Cytotherapy 2009;11(2):129-36. [PubMed: 19152151]

42. Haack-Sorensen M, Bindslev L, Mortensen S, Friis T, Kastrup J. The influence of freezing and storage on the characteristics and functions of human mesenchymal stromal cells isolated for clinical use. Cytotherapy 2007;9(4):328-37. [PubMed: 17573608]

43. Neuhuber B, Swanger SA, Howard L, Mackay A, Fischer I. Effects of plating density and culture time on bone marrow stromal cell characteristics. Experimental hematology 2008 Sep;36(9):117685. [PubMed: 18495329]

44. Muller I, Kordowich S, Holzwarth C, Spano C, Isensee G, Staiber A, et al. Animal serum-free culture conditions for isolation and expansion of multipotent mesenchymal stromal cells from human BM. Cytotherapy 2006;8(5):437-44. [PubMed: 17050248]

45. Lange C, Cakiroglu F, Spiess AN, Cappallo-Obermann H, Dierlamm J, Zander AR. Accelerated and safe expansion of human mesenchymal stromal cells in animal serum-free medium for transplantation and regenerative medicine. J Cell Physiol 2007 Oct;213(1):18-26. [PubMed: 17458897]

46. Le Blanc K, Samuelsson H, Lonnies L, Sundin M, Ringden O. Generation of immunosuppressive mesenchymal stem cells in allogeneic human serum. Transplantation 2007 Oct 27;84(8):1055-9. [PubMed: 17989613]

47. Noort WA, Kruisselbrink AB, in't Anker PS, Kruger M, van Bezooijen RL, de Paus RA, et al. Mesenchymal stem cells promote engraftment of human umbilical cord blood-derived CD34(+) cells in NOD/SCID mice. Experimental hematology 2002 Aug;30(8):870-8. [PubMed: 12160838]

48. Bensidhoum M, Chapel A, Francois S, Demarquay C, Mazurier C, Fouillard L, et al. Homing of in vitro expanded Stro-1- or Stro-1+ human mesenchymal stem cells into the NOD/SCID mouse and their role in supporting human CD34 cell engraftment. Blood 2004 May 1;103(9):3313-9. [PubMed: $14715641]$ 
49. Lazarus HM, Haynesworth SE, Gerson SL, Rosenthal NS, Caplan AI. Ex vivo expansion and subsequent infusion of human bone marrow-derived stromal progenitor cells (mesenchymal progenitor cells): implications for therapeutic use. Bone marrow transplantation 1995 Oct;16(4):55764. [PubMed: 8528172]

50. Koc ON, Gerson SL, Cooper BW, Dyhouse SM, Haynesworth SE, Caplan AI, et al. Rapid hematopoietic recovery after coinfusion of autologous-blood stem cells and culture-expanded marrow mesenchymal stem cells in advanced breast cancer patients receiving high-dose chemotherapy. J Clin Oncol 2000 Jan;18(2):307-16. [PubMed: 10637244]

51. Lazarus HM, Koc ON, Devine SM, Curtin P, Maziarz RT, Holland HK, et al. Cotransplantation of HLA-identical sibling culture-expanded mesenchymal stem cells and hematopoietic stem cells in hematologic malignancy patients. Biol Blood Marrow Transplant 2005 May;11(5):389-98. [PubMed: 15846293]

52. Le Blanc K, Samuelsson H, Gustafsson B, Remberger M, Sundberg B, Arvidson J, et al. Transplantation of mesenchymal stem cells to enhance engraftment of hematopoietic stem cells. Leukemia 2007 Aug;21(8):1733-8. [PubMed: 17541394]

53. Ball LM, Bernardo ME, Roelofs H, Lankester A, Cometa A, Egeler RM, et al. Cotransplantation of ex vivo expanded mesenchymal stem cells accelerates lymphocyte recovery and may reduce the risk of graft failure in haploidentical hematopoietic stem-cell transplantation. Blood 2007 Oct 1;110(7): 2764-7. [PubMed: 17638847]

54. Macmillan ML, Blazar BR, DeFor TE, Wagner JE. Transplantation of ex-vivo culture-expanded parental haploidentical mesenchymal stem cells to promote engraftment in pediatric recipients of unrelated donor umbilical cord blood: results of a phase I-II clinical trial. Bone marrow transplantation 2009 Mar;43(6):447-54. [PubMed: 18955980]

55. Fang B, Li N, Song Y, Li J, Zhao RC, Ma Y. Cotransplantation of haploidentical mesenchymal stem cells to enhance engraftment of hematopoietic stem cells and to reduce the risk of graft failure in two children with severe aplastic anemia. Pediatric transplantation. 2008 Jul 30;

56. Stagg J, Galipeau J. Immune plasticity of bone marrow-derived mesenchymal stromal cells. Handbook of experimental pharmacology 2007;(180):45-66. [PubMed: 17554504]

57. Noel D, Djouad F, Bouffi C, Mrugala D, Jorgensen C. Multipotent mesenchymal stromal cells and immune tolerance. Leukemia \& lymphoma 2007 Jul;48(7):1283-9. [PubMed: 17613755]

58. Nauta AJ, Fibbe WE. Immunomodulatory properties of mesenchymal stromal cells. Blood. 2007 Jul 30;

59. Ryan JM, Barry FP, Murphy JM, Mahon BP. Mesenchymal stem cells avoid allogeneic rejection. Journal of inflammation (London, England) 2005 Jul 26;2:8.

60. Barrett AJ, Le Blanc K. Prophylaxis of acute GVHD: manipulate the graft or the environment? Best Pract Res Clin Haematol 2008 Jun;21(2):165-76. [PubMed: 18503984]

61. Oh H, Loberiza FR Jr, Zhang MJ, Ringden O, Akiyama H, Asai T, et al. Comparison of graft-versushost-disease and survival after HLA-identical sibling bone marrow transplantation in ethnic populations. Blood 2005 Feb 15;105(4):1408-16. [PubMed: 15486071]

62. Devine SM, Hoffman R. Role of mesenchymal stem cells in hematopoietic stem cell transplantation. Current opinion in hematology 2000 Nov;7(6):358-63. [PubMed: 11055509]

63. Koc ON, Lazarus HM. Mesenchymal stem cells: heading into the clinic. Bone marrow transplantation 2001 Feb;27(3):235-9. [PubMed: 11277170]

64. Le Blanc K, Rasmusson I, Sundberg B, Gotherstrom C, Hassan M, Uzunel M, et al. Treatment of severe acute graft-versus-host disease with third party haploidentical mesenchymal stem cells. Lancet 2004 May 1;363(9419):1439-41. [PubMed: 15121408]

65. Ringden O, Uzunel M, Rasmusson I, Remberger M, Sundberg B, Lonnies H, et al. Mesenchymal Stem Cells for Treatment of Therapy-Resistant Graft-versus-Host Disease. Transplantation 2006;81 (10):1390-7. [PubMed: 16732175]

66. Le Blanc K, Frassoni F, Ball L, Locatelli F, Roelofs H, Lewis I, et al. Mesenchymal stem cells for treatment of steroid-resistant, severe, acute graft-versus-host disease: a phase II study. Lancet 2008 May 10;371(9624):1579-86. [PubMed: 18468541] 
67. von Bonin M, Stolzel F, Goedecke A, Richter K, Wuschek N, Holig K, et al. Treatment of refractory acute GVHD with third-party MSC expanded in platelet lysate-containing medium. Bone marrow transplantation 2009 Feb;43(3):245-51. [PubMed: 18820709]

68. Muller I, Kordowich S, Holzwarth C, Isensee G, Lang P, Neunhoeffer F, et al. Application of multipotent mesenchymal stromal cells in pediatric patients following allogeneic stem cell transplantation. Blood cells, molecules \& diseases 2008 Jan-Feb;40(1):25-32.

69. Ning H, Yang F, Jiang M, Hu L, Feng K, Zhang J, et al. The correlation between cotransplantation of mesenchymal stem cells and higher recurrence rate in hematologic malignancy patients: outcome of a pilot clinical study. Leukemia 2008 Mar;22(3):593-9. [PubMed: 18185520]

70. Ringden O, Uzunel M, Sundberg B, Lonnies L, Nava S, Gustafsson J, et al. Tissue repair using allogeneic mesenchymal stem cells for hemorrhagic cystitis, pneumomediastinum and perforated colon. Leukemia 2007 Nov;21(11):2271-6. [PubMed: 17611560]

71. Le Blanc K. Mesenchymal stromal cells: Tissue repair and immune modulation. Cytotherapy 2006;8 (6):559-61. [PubMed: 17148032]

72. Zuk PA, Zhu M, Mizuno H, Huang J, Futrell JW, Katz AJ, et al. Multilineage cells from human adipose tissue: implications for cell-based therapies. Tissue Eng 2001 Apr;7(2):211-28. [PubMed: 11304456]

73. In't Anker PS, Scherjon SA, Kleijburg-van der Keur C, de Groot-Swings GM, Claas FH, Fibbe WE, et al. Isolation of mesenchymal stem cells of fetal or maternal origin from human placenta. Stem Cells 2004;22(7):1338-45. [PubMed: 15579651]

74. Bieback K, Kern S, Kluter H, Eichler H. Critical parameters for the isolation of mesenchymal stem cells from umbilical cord blood. Stem Cells 2004;22(4):625-34. [PubMed: 15277708]

75. in't Anker PS, Noort WA, Scherjon SA, Kleijburg-van der Keur C, Kruisselbrink AB, van Bezooijen RL, et al. Mesenchymal stem cells in human second-trimester bone marrow, liver, lung, and spleen exhibit a similar immunophenotype but a heterogeneous multilineage differentiation potential. Haematologica 2003 Aug;88(8):845-52. [PubMed: 12935972]

76. Puissant B, Barreau C, Bourin P, Clavel C, Corre J, Bousquet C, et al. Immunomodulatory effect of human adipose tissue-derived adult stem cells: comparison with bone marrow mesenchymal stem cells. British journal of haematology 2005 Apr;129(1):118-29. [PubMed: 15801964]

77. Yanez R, Lamana ML, Garcia-Castro J, Colmenero I, Ramirez M, Bueren JA. Adipose tissue-derived mesenchymal stem cells have in vivo immunosuppressive properties applicable for the control of the graft-versus-host disease. Stem Cells 2006 Nov;24(11):2582-91. [PubMed: 16873762]

78. Keyser KA, Beagles KE, Kiem HP. Comparison of mesenchymal stem cells from different tissues to suppress T-cell activation. Cell transplantation 2007;16(5):555-62. [PubMed: 17708345]

79. Fang B, Song Y, Lin Q, Zhang Y, Cao Y, Zhao RC, et al. Human adipose tissue-derived mesenchymal stromal cells as salvage therapy for treatment of severe refractory acute graft-vs.-host disease in two children. Pediatric transplantation 2007 Nov;11(7):814-7. [PubMed: 17910665]

80. Fang B, Song Y, Zhao RC, Han Q, Lin Q. Using human adipose tissue-derived mesenchymal stem cells as salvage therapy for hepatic graft-versus-host disease resembling acute hepatitis. Transplantation proceedings 2007 Jun;39(5):1710-3. [PubMed: 17580228]

81. Fang B, Song Y, Liao L, Zhang Y, Zhao RC. Favorable response to human adipose tissue-derived mesenchymal stem cells in steroid-refractory acute graft-versus-host disease. Transplantation proceedings 2007 Dec;39(10):3358-62. [PubMed: 18089385]

82. Martin-Donaire T, Rico M, Bautista G, Gonzalo-Daganzo R, Regidor C, Ojeda E, et al. Immune reconstitution after cord blood transplants supported by coinfusion of mobilized hematopoietic stem cells from a third party donor. Bone marrow transplantation. 2009 Mar 2;

83. Gonzalo-Daganzo R, Regidor C, Martin-Donaire T, Rico MA, Bautista G, Krsnik I, et al. Results of a pilot study on the use of third-party donor mesenchymal stromal cells in cord blood transplantation in adults. Cytotherapy 2009 Mar;23:1-11.

84. Brooke G, Rossetti T, Pelekanos R, Ilic N, Murray P, Hancock S, et al. Manufacturing of human placenta-derived mesenchymal stem cells for clinical trials. British journal of haematology $2009 \mathrm{Feb}$; 144(4):571-9. [PubMed: 19077161] 
85. Robinson SN, Ng J, Niu T, Yang H, McMannis JD, Karandish S, et al. Superior ex vivo cord blood expansion following co-culture with bone marrow-derived mesenchymal stem cells. Bone marrow transplantation 2006 Feb;37(4):359-66. [PubMed: 16400333]

86. McNiece I, Harrington J, Turney J, Kellner J, Shpall EJ. Ex vivo expansion of cord blood mononuclear cells on mesenchymal stem cells. Cytotherapy 2004;6(4):311-7. [PubMed: 16146883]

87. Karnoub AE, Dash AB, Vo AP, Sullivan A, Brooks MW, Bell GW, et al. Mesenchymal stem cells within tumour stroma promote breast cancer metastasis. Nature 2007 Oct 4;449(7162):557-63. [PubMed: 17914389]

88. Kidd S, Spaeth E, Klopp A, Andreeff M, Hall B, Marini FC. The (in) auspicious role of mesenchymal stromal cells in cancer: be it friend or foe. Cytotherapy 2008;10(7):657-67. [PubMed: 18985472] 


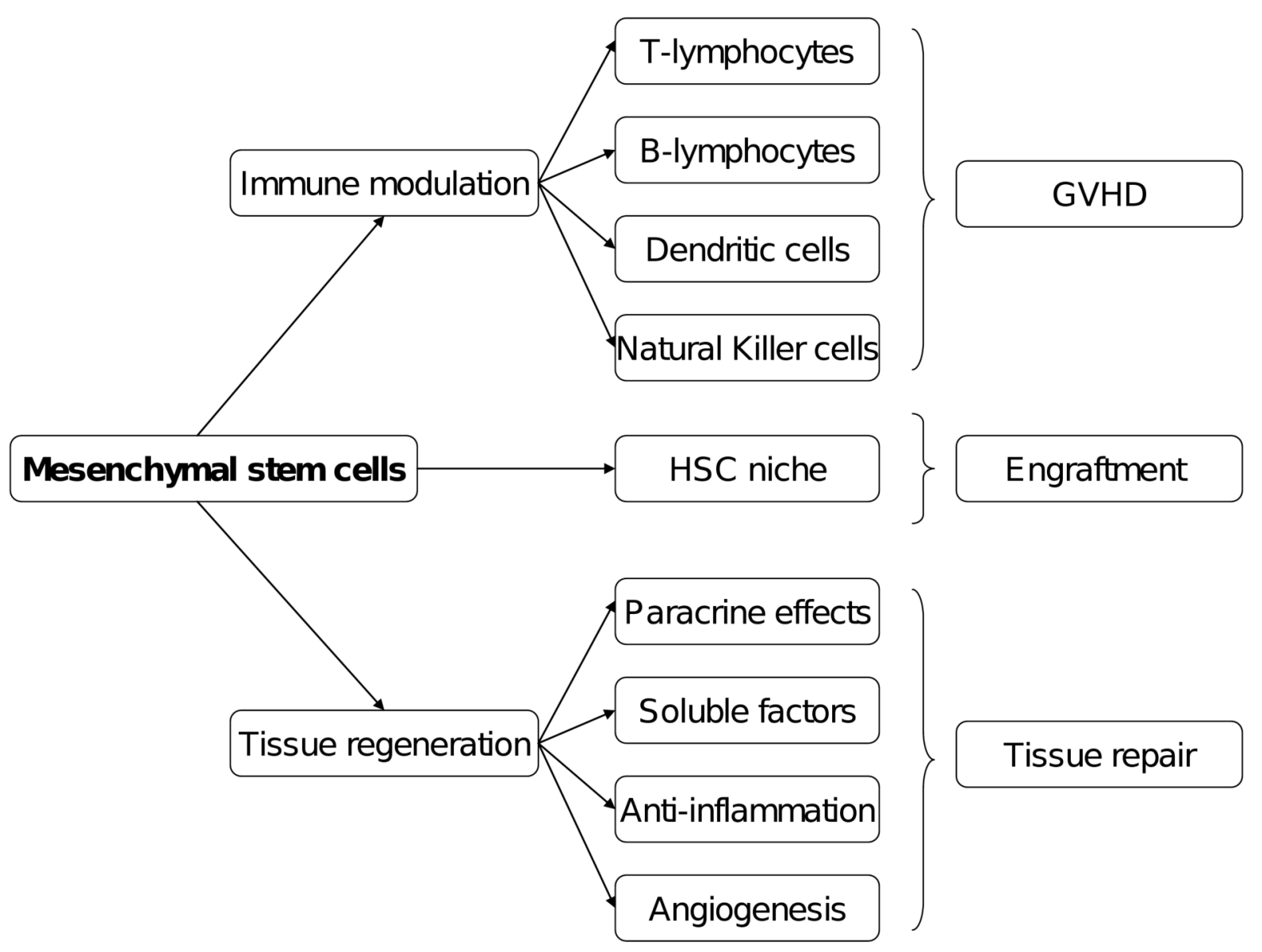

Figure 1.

Mechanisms of action and potential role of mesenchymal stem cells in hematopoietic stem cell transplantation. 


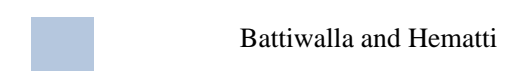

Page 15

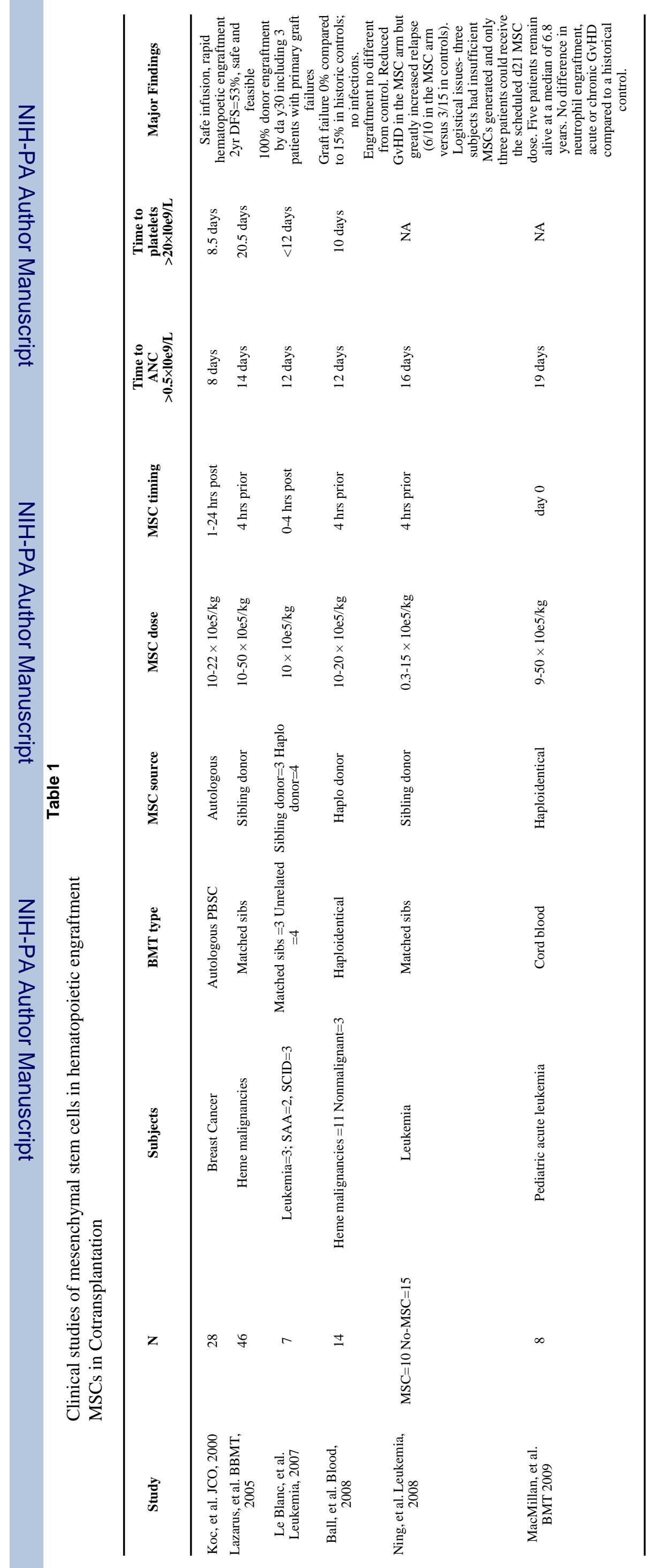




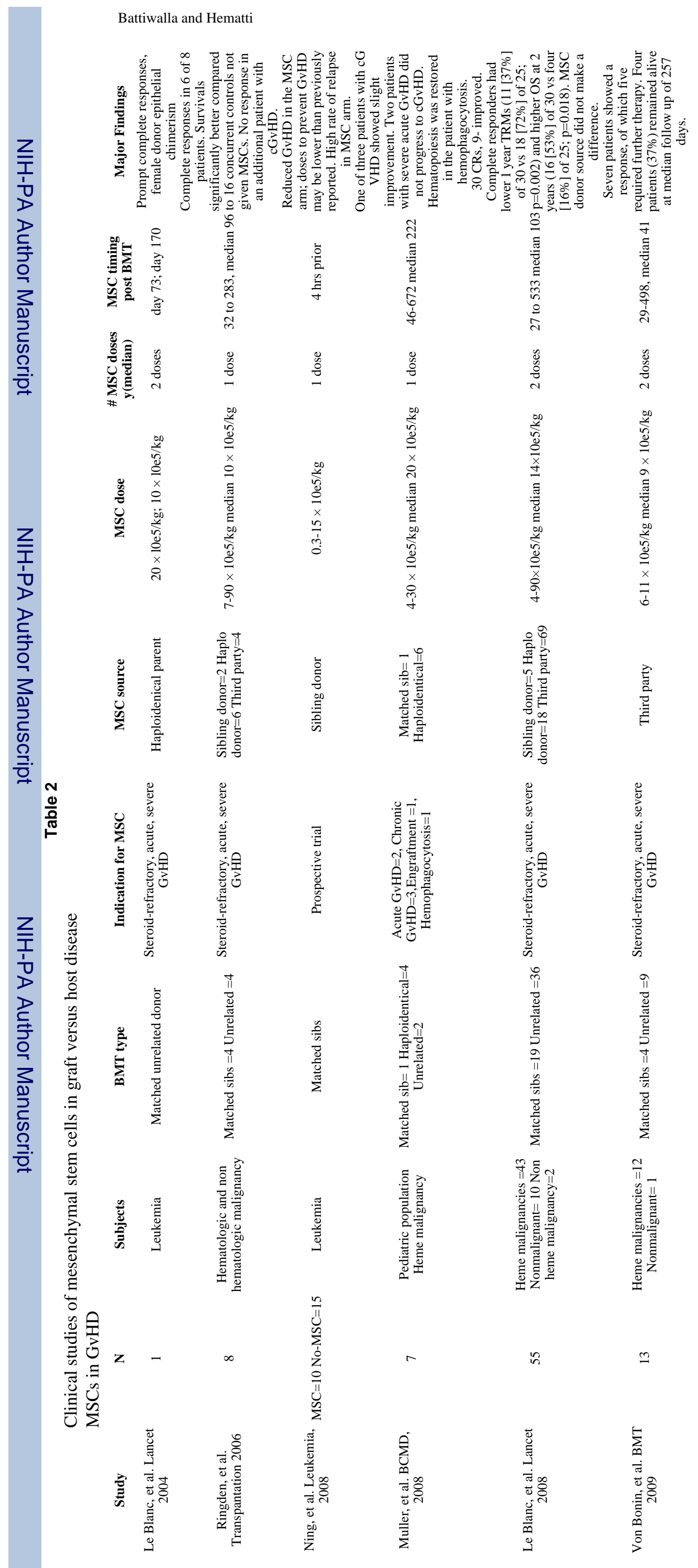

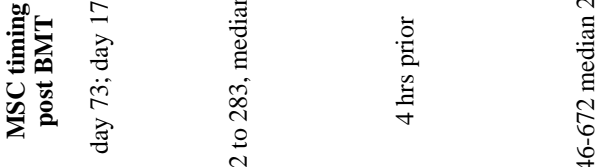

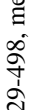




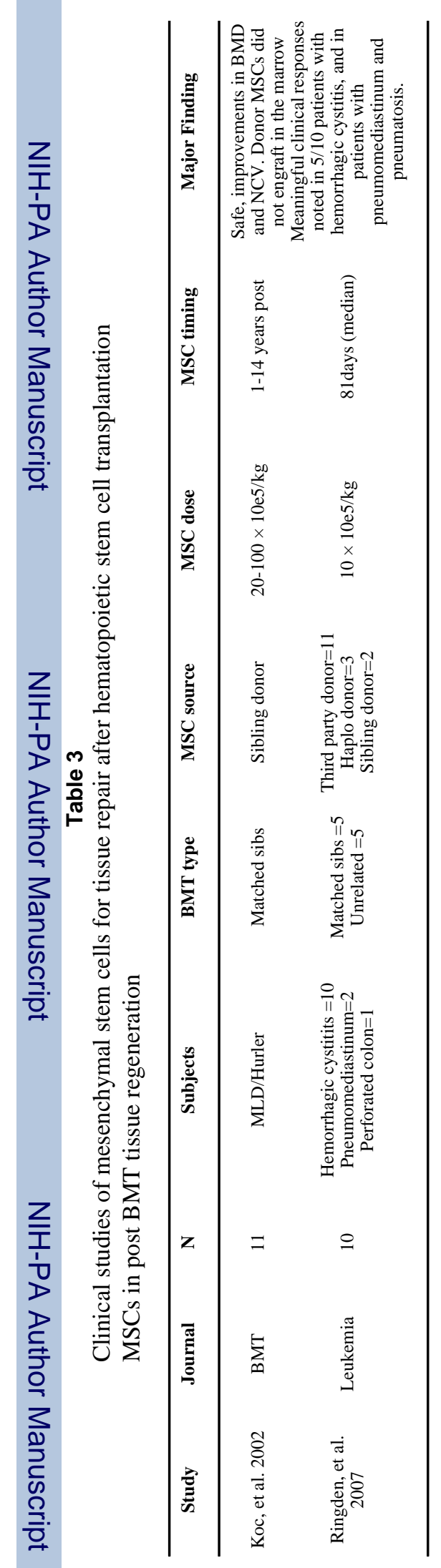

Cytotherapy. Author manuscript; available in PMC 2010 January 1. 